\title{
Functional microbial communities in high arsenic groundwater
}

\author{
P. Li, Z. Jiang \& Y.X. Wang \\ China University of Geosciences, Wuhan, P.R. China
}

\begin{abstract}
Microbial functional potential in high arsenic (As) groundwater remains largely unknown. In this study, the microbial community functional composition of high arsenic groundwater samples from Hetao Basin, China, was investigated using integrated methods including DGGE, gene clone library, qPCR, and GeoChip. The results showed that As-related genes ( $\operatorname{ars} C$ and $\operatorname{arr} A$ ), sulfate-related genes $(d s r A$ and $d s r B$ ), and methanogen genes $(m c r A)$ were correlated with $\mathrm{As}, \mathrm{SO}_{4}^{2-}$, or $\mathrm{CH}_{4}$ concentrations in groundwater, respectively. Arsenic, total organic content, $\mathrm{SO}_{4}^{2-}, \mathrm{NH}_{4}^{+}$, oxidation-reduction potential (ORP), and $\mathrm{pH}$ were important factors shaping the functional microbial community structure. Alkaline and reducing conditions associated with microbiallymediated geochemical processes could be linked to As enrichment in groundwater.
\end{abstract}

\section{INTRODUCTION}

Arsenic (As) in groundwater is a serious environmental issue due to its widespread distribution and high toxicity, which threatens the health of millions of people worldwide. Previous studies showed that As mobilization and transformation could be ascribed to the complex interactions between microbes and geochemical processes and that microbes play key roles in driving the biogeochemical cycle in high As groundwater aquifers (Li et al., 2014, 2017; Wang et al., 2015). The integrated role of various functional microbial populations on As mobilization in groundwater remained unknown. To investigate the functional potential microbial community structures in high As groundwater aquifers, we used a series of technologies including DGGE, gene clone library, qPCR, and GeoChip, which targets functional gene families involved in As, C, and S geochemical cycling.

\section{METHODS}

\subsection{Sample collection and geochemistry measurements}

Groundwater samples were collected from tubewells with a depth range of $20-30 \mathrm{~m}$ from Hetao Basin, Inner Mongolia. Microbial samples were collected by on-line filtering of $5-10 \mathrm{~L}$ water through 0.22 $\mu \mathrm{m}$ filters. Water $\mathrm{pH}$, electrolytic conductivity (EC), oxidation-reduction potential (ORP), total dissolved solids (TDS), dissolved oxygen (DO), ammonium, sulfide, ferrous iron ( $\mathrm{Fe}(\mathrm{II})$ ), and total iron were measured in the field using portable hand-held meters. The measurements of cation, anion, dissolved organic carton
(DOC), total carbon (TC), total nitrogen (TN), $\mathrm{CH}_{4}$, and As species were performed in the laboratory.

\subsection{DNA extraction and functional gene detection}

DNA for all groundwater samples was extracted using FastDNA spin kits for soil according to the manufacturer's manual. DNA concentrations were quantified by PicoGreen, using a FLUO star Optima instrument. The $d s r B$ gene structure were investigated using denaturing gradient gel electrophoresis (DGGE). The functional communities of $m c r A$ genes and arsenic related genes including aio $A$, $\operatorname{ars} C$, and $\operatorname{arr} A$ were detected with gene clone library method. N, C, S and As related genes were qualified by qPCR and geochip. For geochip detection, 500 ng of DNA was labeled with $\mathrm{Cy}$. The labeled DNA was re-suspended in hybridization solution, and then hybridized in an Agilent hybridization oven at $67^{\circ} \mathrm{C}$ for $24 \mathrm{~h}$. After hybridization, the arrays were scanned with a NimbleGen MS200 Microarray Scanner. The images were extracted by the Agilent Feature Extraction program. Poor quality spots with a signal-to-noise ratio of less than 2.0 were removed before statistical analysis. The positive signals were normalized within each sample and across all samples.

\subsection{Statistical analysis}

Data were further analyzed by the Vegan package in R 3.1.1 (http://www.r-project.org/). Hierarchical clustering was performed with CLUSTER 3.0 were visualized in TREEVIEW. Canonical correspondence 
analysis (CCA) were performed to link microbial communities to environmental variables.

\section{RESULTS AND DISCUSSION}

\subsection{Geochemistry}

Groundwater samples could be divided into welldefined high and low As groups based on geochemistry. Samples with high As concentrations generally had low concentrations of sulfate, negative ORP, and relatively high concentrations of $\mathrm{As}(\mathrm{III}), \mathrm{Fe}(\mathrm{II}), \mathrm{CH}_{4}$, $\mathrm{NH}_{4}^{+}$, and TOC contents. These geochemical characteristics indicated that alkaline and reducing conditions could be linked to natural As enrichment in groundwater.

\subsection{Functional microbial communities}

Analysis of aioA gene clone library found that Asoxidizing bacteria in high As groundwater of Hetao Plain belonged to Rhodoferax ferrireducens, Leptothrix sp.,Acidovorax sp., Pseudomonas, Acinetobacter, Xanthobacter autotrophicus, Bradyrhizobium sp., Bosea sp., Aminobacter sp. and Nitrobacter hamburgensis. As-reducing populations in high As groundwater mainly belonged to Geobacter sp., Desulfosporosinus sp., Chrysiogenes and Desulfurispirillum. Most of these populations were found capable of dissimilatory arsenate reducing or sulfur oxidizing in previously studies.

Clone library result of $m c r A$ gene indicated methanogens in high As groundwater were mainly composed of Methanomicrobia, Methanobacteria and the uncultured group, among which $83 \%$ clones belonged to Methanomicrobia including Methanomicrobiales and Methanosarcinales.

Sulfate reducing bacteria in high As groundwater were mainly dominated by Desulfotomaculum, Desulfobulbus, Desulfosarcina and Desulfobacca. Most of the functional populations were found capable of both arsenate reducing and sulfur reducing.

\subsection{The abundance of functional genes}

The number of detected As related genes ars $C$ $(\mathrm{r}=0.462, \mathrm{p}<0.01)$ and $\operatorname{arr} A(\mathrm{r}=0.486, \mathrm{p}<0.01)$ have positive correlations with As concentration. More $\operatorname{ars} C / \operatorname{ars} B$ genes were detected than the other genes, such as $\operatorname{arr} A$ (around 5-8 folds), indicating that the most common detoxification mechanism was reduction of $\mathrm{As}(\mathrm{V})$ to $\mathrm{As}(\mathrm{III})$ rather than respiratory arsenate reduction in the high arsenic groundwater aquifers. Besides, As detoxification genes $\operatorname{ars} C$ and $\operatorname{ars} B$, and the respiratory arsenate $(\mathrm{As}(\mathrm{V}))$ reductase gene $\operatorname{arr} A$ had higher relative abundances in the high As group than low As group.
There were positive correlations between As and sulfur reduction genes $(d s r B$ and As: $r=0.327$, $\mathrm{p}<0.05$ ). Positive correlations were also observed between methanogenesis genes and As and methane concentrations (mcrA: $\mathrm{r}=0.549, \mathrm{p}<0.05 ; \mathrm{r}=0.314$, $\mathrm{p}<0.05$, respectively). These results indicated that sulfur reduction and methanogenesis might be an important metabolic process and accelerate As release and accumulation in high arsenic aquifers.

\subsection{Functional microbial community structure in relation to geochemistry}

Significant differences were observed in functional microbial structure between low and high As groups $(\mathrm{r}=0.4776, \mathrm{p}=0.007)$. Six environmental variables, Astot, $\mathrm{SO}_{4}^{2-}, \mathrm{NH}_{4}^{+}, \mathrm{pH}, \mathrm{ORP}$, and TOC were the most significant environmental variables shaping the microbial community structure $(\mathrm{p}=0.021)$. Group $1\left(\mathrm{SO}_{4}^{2-}\right.$, ORP) explained $22.63 \%(\mathrm{p}=0.010)$, and group 2 $\left(\mathrm{As}_{\mathrm{Tot}}\right.$, TOC and $\left.\mathrm{NH}_{4}^{+}\right)$explained $24.98 \%(\mathrm{p}=0.010)$. The $\mathrm{pH}$ (group 3) independently explained 17.64\% $(p=0.005)$ of the observed variation. About 58.80\% of the community functional variation remained unexplained by the above selected variables.

\section{CONCLUSIONS}

Our results reveal that environmental variables account for the majority of variation in microbial functional potential and provides evidence for possible links between $\mathrm{As}, \mathrm{S}$, and $\mathrm{C}$ related microbial functional gene abundances and As geochemistry. Alkaline and reducing conditions associated with microbially-mediated geochemical processes could be linked to As enrichment in groundwater in this study area.

\section{ACKNOWLEDGEMENTS}

This work was financially supported by National Natural Science Foundation of China (grant numbers 41372348, 41521001).

\section{REFERENCES}

Li, P., Li, B., Webster, G., Wang, Y., Jiang, D., Dai, X., Jiang, Z., Dong, H. \& Wang, Y. 2014. Abundance and diversity of sulfate-reducing bacteria in high arsenic shallow aquifers. Geomicrobiol. J. 31(9): 802-812.

Li, P., Jiang, Z., Wang, Y., Deng, Y., Van Nostrand, J.D., Yuan, T., Liu, H., Wei, D. \& Zhou, J. 2017. Analysis of the functional gene structure and metabolic potential of microbial community in high arsenic groundwater. Water Res. 123: 268-276.

Wang, Y., Li, P., Dai, X., Zhang, R., Jiang, Z., Jiang, D. \& Wang, Y. 2015. Abundance and diversity of methanogens: potential role in high arsenic groundwater in Hetao plain of inner Mongolia, China. Sci. Total Environ. 515: 153-161. 